\title{
Factors affecting presence and relative abundance of the Endangered volcano rabbit Romerolagus diazi, a habitat specialist
}

\author{
Felipe Osuna, Roger Guevara, Enrique Martínez-Meyer \\ Raúl Alcalá and Alejandro Espinosa de los Monteros
}

\begin{abstract}
Habitat specialists are particularly vulnerable to extinction when habitat conditions are altered. Information on the habitat use of such species is thus important because it provides insight into factors that influence distribution and abundance, which is crucial for conservation. Here, we aimed to identify factors that influence the patterns of presence and abundance of the Endangered volcano rabbit Romerolagus diazi, a rare leporid with a patchy distribution. Through exhaustive sampling of its range in the Sierra Chichinautzin and Sierra Nevada volcanic fields, Mexico, and using generalized linear models, we found that the probability of patch occupancy was higher where bunchgrass cover exceeded $75 \%$, rock cover exceeded $5 \%$, no cattle grazing was observed and human settlements were at least $7 \mathrm{~km}$ away. Patches with greater relative abundance were those with similar characteristics, but located at elevations $>3,600 \mathrm{~m}$, and with rock cover $<15 \%$. Cattle grazing was identified as a major threat to local populations of the volcano rabbit, particularly in the Sierra Chichinautzin. Because of the significance of bunchgrasses for this species, the protection of the mountain grasslands is required in both volcanic fields.
\end{abstract}

Keywords Anthropogenic disturbance, bunchgrass cover, cattle grazing, conservation, Leporidae, Romerolagus diazi, volcano rabbit

Supplementary material for this article is available at doi.org/10.1017/So030605320000368

\section{Introduction}

wo major challenges in studying wildlife ecology are the 1 characterization of habitat use and the identification of

Felipe Osuna (iD orcid.org/0000-0003-2148-6583), Roger Guevara and Alejandro Espinosa de los Monteros (Corresponding author, (D) orcid.org/ 0000-0002-7742-5977) Departamento de Biología Evolutiva, Instituto de Ecología AC, Carretera Antigua a Coatepec 351, El Haya, Xalapa 91070, Veracruz, Mexico. E-mail alejandro.espinosa@inecol.mx

Enrique Martínez-Meyer Instituto de Biología, Universidad Nacional Autónoma de México, Ciudad Universitaria, Mexico City, Mexico

Raúl AlCalá Departamento de Ecología Evolutiva, Centro de Investigación en Biodiversidad y Conservación, Universidad Autónoma del Estado de Morelos, Morelos, Mexico

Received 19 June 2019. Revision requested 10 September 2019.

Accepted 20 April 2020. First published online 19 March 2021. factors limiting a species' distribution. Habitat generalists can tolerate a broad spectrum of environmental conditions, whereas specialists are restricted to a limited set of environmental conditions, which restricts their areas of distribution and makes them more vulnerable to disturbance and loss of specific habitat resources (Crown \& van Riper, 2010). Where a species lies along this generalist-specialist continuum affects its population dynamics (Kolasa \& Li, 2003). In the current context of global environmental change (e.g. through climate change, habitat loss and pollution) it is a priority to document habitat use by specialist species, and to consider natural and anthropogenic factors that influence their distribution. Such studies facilitate the identification not only of habitat units within the landscape that could potentially support viable populations, but also of factors that limit the species' distribution. In particular, this information is fundamental for mitigation measures that encourage habitat occupation, which is a priority for the conservation of threatened species (Edgel et al., 2014).

The volcano rabbit Romerolagus diazi (also known as zacatuche or teporingo) is a mountain habitat specialist endemic to the Sierra Chichinautzin and Sierra Nevada volcanic fields in the Trans-Mexican Volcanic Belt. It is associated with patches containing bunchgrasses (e.g. Muhlenbergia spp. and Festuca spp.) that have a fragmented distribution within forests at elevations of 2,800-4,200 m (Velázquez et al., 1996). There is increasing anthropogenic pressure on volcano rabbit populations. Cattle grazing, logging and land conversion for agriculture lead to habitat modification, fragmentation and loss (Galicia \& García-Romero, 2007; Arregoitia et al., 2015). As a result, the volcano rabbit is categorized as Endangered on the IUCN Red List (Velázquez \& Guerrero, 2019), and considered in danger of extinction by Mexican laws (SEMARNAT, 2010).

High abundance of this lagomorph has been recorded in sites covered by grass species with a bunch type growth habit (Festuca tolucensis and Festuca tolucensis-Trisetum altijugum), followed by bunchgrasses associated with pine forests (Muhlenbergia quadridentata and F. tolucensis associated with Pinus hartwegii; Velázquez \& Heil, 1996). However, the rabbit's preference for biological and structural habitat features varies locally. On the Pelado volcano in the Sierra Chichinautzin, rabbit populations occurred mainly in mixed forests (Pinus spp.-Alnus spp.; Fa et al., 1992). On some volcanoes in the southern Sierra Chichinautzin, at 
elevations of 2,760-3,250 m, the species' abundance was influenced by the patch size and cover extent of bunchgrasses, and the presence of shrubs (Rizo-Aguilar et al., 2015, 2016; Uriostegui-Velarde et al., 2018). On the Iztaccíhuatl volcano in the Sierra Nevada $(3,400-4,000 \mathrm{~m})$, forest cover and cattle grazing correlated negatively with habitat occurrence for this species, whereas population abundance increased with distance from the surveillance facilities of the Izta-Popo National Park (Hunter \& Cresswell, 2015).

All previous studies were carried out in specific locations at restricted elevation ranges. It is unknown whether the differences observed between sites are a consequence of specific local conditions or constitute a general pattern of habitat use by the volcano rabbit across its range. Therefore, we considered the entire known range of this species, including the two major volcanic ranges, its full elevational range and all suitable habitats in these landscapes. We aimed to answer the following questions: (1) which factors (biotic, abiotic and anthropogenic) influence patch occupancy and relative abundance of the volcano rabbit, and (2) to what extent is cattle grazing a threat to its populations? Given the known association of volcano rabbits with bunchgrasses, we predicted: (1) a positive correlation between both patch occupancy and relative abundance with per cent bunchgrass cover, and (2) reduced patch occupancy and relative abundance in areas grazed by cattle.

\section{Study area}

This work was carried out in the Sierra Chichinautzin and Sierra Nevada volcanic fields. These mountains are located in the eastern Trans-Mexican Volcanic Belt, adjacent to Mexico City, one of the world's largest urban centres. Together, these volcanic fields encompass the global range of the species (Hunter \& Cresswell, 2015). The Sierra Chichinautzin comprises more than 200 volcanoes, whereas the Sierra Nevada consists of only five large volcanoes, including Popocatépetl $(5,426 \mathrm{~m})$ and Iztaccíhuatl $(5,230 \mathrm{~m})$, the second and third highest in Mexico (Márquez et al., 1999). Vegetation cover is temperate forests (e.g. Quercus spp., Pinus spp. and Abies spp.) and subalpine and alpine grasslands (e.g. Muhlenbergia spp., Festuca spp. and Calamagrostis spp.; Rzedowski, 1988). We observed seven species of bunchgrasses that can be used by the volcano rabbit: Muhlenbergia macroura, $M$. quadridentata, F. tolucensis, Festuca rosaceae, Festuca amplissima, Calamagrostis tolucensis and Stipa ichu. The dominant species were $M$. macroura and $F$. tolucensis, which were present in $>90 \%$ of the patches occupied by the volcano rabbit. The Sierra Chichinautzin and Sierra Nevada harbour a great diversity of vertebrates, including some micro-endemic high mountain specialists such as the volcano axolotl Ambystoma leorae (Monroy et al., 2011). There are numerous human settlements in the area, and associated agricultural and forestry activities (Galicia \& García-Romero, 2007). The forest is the main source of income and energy (i.e. fuel for cooking and heating) for local communities (Trejo \& Dirzo, 2000). There are four main land-use types in the region: cropland, pastures for livestock grazing, forests (used for timber and firewood extraction) and urban areas. Other activities include hunting and the extraction of fertile soil that is sold for use in gardening (Velázquez et al., 1996; Galicia \& García-Romero, 2007).

Despite their geographical proximity, there are profound differences between the two mountain ranges. Habitat patches in the Sierra Chichinautzin are small and isolated by a forest matrix with agricultural fields, with high levels of human disturbance (forest exploitation and cattle grazing; Table 1). Environmental conditions in the Sierra Chichinautzin are warmer and drier than in the Sierra Nevada and thus less favourable for the growth of bunchgrasses. In addition, urban pressure is higher because the Sierra Chichinautzin is near Mexico City and Cuernavaca. In the Sierra Nevada patches of grassland are larger, more connected and less affected by human activities, presenting more favourable conditions for the volcano rabbit.

\section{Methods}

\section{Survey design}

Based on historical records of the volcano rabbit (Velázquez et al., 1996; Domínguez, 2007; Osuna et al., 2020) we delimited the possible range of the species in both volcanic fields as areas at 2,900-4,350 m altitude. During 2016 and 2017 we surveyed a total of $770 \mathrm{~km}^{2}$ in search for patches with dense bunchgrass cover that could be suitable habitat for the volcano rabbit (Velazquez \& Heil, 1996). In areas with fragmented habitats, we considered bunchgrass patches that were at least $250 \mathrm{~m}$ apart as independent sites. We found 165 independent sites of bunchgrass patches adequate for the presence of volcano rabbits. We marked a $20 \times 20 \mathrm{~m}$ quadrant in each patch (Mueller-Dombois \& Ellenberg, 1974), to determine the presence of volcano rabbits and gather data about environmental variables considered to be associated with habitat quality. We placed the sample quadrant near the centre of each patch, avoiding roads or areas that showed clear evidence of human alteration. We placed metal posts at the quadrant corners and marked the perimeter with a rope tied to the corner posts. Using cotton thread tied to the perimeter ropes at $2 \mathrm{~m}$ intervals, we divided each quadrant into $4 \mathrm{~m}^{2}$ grid cells, to take fine-scale measurements of environmental variables.

The volcano rabbit is secretive and shy, hiding in burrows at any perceived danger, which means direct observation is rarely possible. We therefore used the indirect method of excreta presence to infer patch occupancy. This 
TABLE 1 Variables influencing the presence and relative abundance of the volcano rabbit Romerolagus diazi throughout its range in the Sierra Chichinautzin and the Sierra Nevada, Mexico.

\begin{tabular}{|c|c|c|c|c|c|c|}
\hline \multirow[b]{2}{*}{ Variable } & \multicolumn{2}{|l|}{ Unoccupied patches } & \multirow[b]{2}{*}{$\begin{array}{l}\text { Total } \\
\text { No./Mean } \pm \text { SE }\end{array}$} & \multicolumn{2}{|l|}{ Occupied patches } & \multirow[b]{2}{*}{$\begin{array}{l}\text { Total } \\
\text { No./Mean } \pm \text { SE }\end{array}$} \\
\hline & $\begin{array}{l}\text { Sierra Chichinautzin } \\
\text { No./Mean } \pm \mathrm{SE}\end{array}$ & $\begin{array}{l}\text { Sierra Nevada } \\
\text { No./Mean } \pm \text { SE }\end{array}$ & & $\begin{array}{l}\text { Sierra Chichinautzin } \\
\text { No./Mean } \pm \text { SE }\end{array}$ & $\begin{array}{l}\text { Sierra Nevada } \\
\text { No./Mean } \pm \text { SE }\end{array}$ & \\
\hline Analysed patches & 53 & 41 & 94 & 44 & 27 & 71 \\
\hline No. of latrines & 0 & 0 & 0 & $54.8 \pm 27.6$ & $65.2 \pm 37.6$ & $58.8 \pm 31.9$ \\
\hline Altitude $^{1,2}(\mathrm{~m})$ & $3,204 \pm 194$ & $3,626 \pm 314$ & $3,388 \pm 328$ & $3,142 \pm 151$ & $3,705 \pm 302$ & $3,356 \pm 351$ \\
\hline Bunchgrass cover ${ }^{1,2}(\%)$ & $78.4 \pm 16.4$ & $78.6 \pm 13.9$ & $78.5 \pm 15.3$ & $82.8 \pm 9.0$ & $82.9 \pm 11.0$ & $82.9 \pm 9.7$ \\
\hline Cattle grazing ${ }^{1,2}$ & 22 & 21 & 43 & 6 & 8 & 14 \\
\hline Forest cover ${ }^{1,2}(\%)$ & $22.7 \pm 23.6$ & $29.9 \pm 27.0$ & $25.8 \pm 25.3$ & $25.2 \pm 18.3$ & $13.7 \pm 17.1$ & $20.8 \pm 18.6$ \\
\hline Herbaceous cover (\%) & $7.6 \pm 11.1$ & $7.6 \pm 8.6$ & $7.6 \pm 10.4$ & $4.4 \pm 4.6$ & $6.5 \pm 8.3$ & $5.2 \pm 6.2$ \\
\hline Human impact index & $0.8 \pm 0.2$ & $0.5 \pm 0.2$ & $0.6 \pm 0.2$ & $0.7 \pm 0.2$ & $0.6 \pm 0.1$ & $0.7 \pm 0.2$ \\
\hline Distance to nearest settlement ${ }^{1}(\mathrm{~km})$ & $4.8 \pm 2.0$ & $7.9 \pm 2.8$ & $6.1 \pm 2.2$ & $5.1 \pm 2.3$ & $8.1 \pm 2.9$ & $6.2 \pm 2.9$ \\
\hline Rock cover $^{1,2}(\%)$ & $2.3 \pm 5.4$ & $1.6 \pm 5.7$ & $2.0 \pm 5.5$ & $5.8 \pm 7.4$ & $1.7 \pm 5.1$ & $4.2 \pm 6.9$ \\
\hline Shrubs cover ${ }^{1,2}(\%)$ & $3.7 \pm 6.2$ & $2.1 \pm 5.2$ & $3.0 \pm 5.8$ & $3.7 \pm 4.9$ & $4.1 \pm 5.9$ & $3.8 \pm 5.3$ \\
\hline Terrain slope & $9.9 \pm 7.9$ & $13.0 \pm 8.0$ & $11.2 \pm 8.0$ & $8.7 \pm 6.5$ & $12.5 \pm 6.6$ & $10.1 \pm 6.8$ \\
\hline Sylvilagus cunicularius presence $e^{1,2}$ & 23 & 10 & 33 & 10 & 6 & 16 \\
\hline Sylvilagus floridanus presence & 13 & 2 & 15 & 8 & 6 & 14 \\
\hline No. of mature trees ${ }^{3}$ & $1.2 \pm 1.9$ & $2.5 \pm 3.5$ & $1.8 \pm 2.8$ & $1.2 \pm 1.6$ & $0.8 \pm 1.2$ & $1.1 \pm 1.5$ \\
\hline
\end{tabular}

${ }^{1}$ Variable used in presence model.

${ }^{2}$ Variable used in relative abundance model.

${ }^{3}$ Diameter at breast height $>50 \mathrm{~cm}$. 
is a widely used method for the study of this and other lagomorphs (Krebs et al., 1986; Hunter \& Creswell, 2015). We did not consider individual droppings nor dispersed excreta as evidence for rabbit presence, but searched the entire ground surface of the quadrant for latrines. Latrines are defined as areas with more than 30 fresh faecal pellets grouped together (Santilli et al., 2015), are easy to detect and indicate recent occupation by volcano rabbits. Patches with burrows but without latrines could be abandoned sites. We recorded a site as inhabited by volcano rabbits only when both latrines and burrows were present. One latrine is not necessarily equivalent to one individual, but a positive relationship between the number of latrines and the number of individuals has been suggested (Hunter \& Creswell, 2015; Santilli et al., 2015). Therefore, recording the number of latrines is an indirect way of inferring relative abundance.

\section{Variables related to habitat use}

We recorded a total of 14 variables related to habitat for analysis (Table 1), based on the known natural history of the species (Velázquez et al., 1996) and previous studies on its habitat use (Fa et al., 1992; Hunter \& Creswell, 2015; Rizo-Aguilar et al., 2016). To analyse vegetation cover we measured the per cent cover of bunchgrasses higher than $50 \mathrm{~cm}$, herbaceous plants and shrubs, and counted the number of adult trees with a diameter at breast height of $>50 \mathrm{~cm}$. We quantified forest cover using a spherical densiometer, estimating the value for each site as the mean of the four measurements corresponding to the different cardinal points from the centre of the quadrant. In some instances, different vegetation types (e.g. grass, shrubs, herbaceous plants) overlapped, so the sum of their cover percentages was $>100 \%$ of the quadrant area. We recorded the presence of other rabbits (the Mexican cottontail Sylvilagus cunicularius and eastern cottontail Sylvilagus floridanus) by identifying their excreta, which are easily distinguished from those of the volcano rabbit (Velázquez et al., 1996).

We extracted abiotic variables, including per cent cover of rocks, elevation and slope, from the official Mexican Digital Elevation Model (Mexican Elevation Continuum, CEM 3.0, at $15 \mathrm{~m}$; INEGI, 2013) using QGIS 3.1 (QGIS Development Team, 2009). The identity of the volcanic field (i.e. Sierra Chichinautzin or Sierra Nevada) was included in the analysis as an abiotic factor.

We determined the presence of cattle grazing by livestock sightings, the presence of excreta, and evidence of grazing at or close to the bunchgrass patch. We calculated the distance from the centre of each sample patch to the nearest human settlement using Google Earth Pro (US Department of State Geographer, 2018). This programme accounts for relief and landscape features such as creeks or hills when measuring distances on the Earth's surface. We included in our analysis the human impact index on Mexican biodiversity from MEXBIO (CONABIO, 2018), which is based on the theoretical framework of the Global Biodiversity Model and establishes simple cause-effect relationships between different environmental pressures and threats. We adapted the model for Mexico at a resolution of $1 \mathrm{~km}^{2}$, including factors such as land-use pressure, infrastructure and habitat fragmentation. The distance to human settlements affects local conditions such as habitat quality, whereas the index of human impact mainly influences spatial processes such as species dispersal amongst patches.

\section{Data analysis}

We performed statistical analyses in $R$ 3.3.1 (R Development Core Team, 2012). We created two matrices: (1) presence analysis, to detect variables that influenced patch occupancy, and (2) relative abundance analysis, to detect variables that influenced this parameter. For each matrix we constructed generalized linear models. To assess presence, we built a binomial regression model (presence/absence) with the data from all patches, using the logit link function in $R$. For relative abundance, we constructed a model based only on data from occupied patches, using the gamma distribution and reciprocal link functions in $R$. Given the models' complexity (14 variables and their interactions), we followed a series of steps to find the simplest possible model: (1) We explored each variable using a univariate model, to infer its individual contribution. (2) For each matrix we reduced the number of variables depending on the individual contribution of each variable (Table 1). (3) We evaluated models with all paired interactions between their variables. (4) We performed a stepwise bidirectional simplification procedure employing the Akaike information criterion (AIC) value as a criterion for model selection, using the stepAIC function in the MASS package for $R$. (5) We refined the simplification by comparing models using the difference in variance until we identified the simplest model.

\section{Results}

We detected volcano rabbits in 71 of the 165 patches visited (Fig. 1). The model that best explained their presence retained nine variables and 12 interactions, accounting for $47 \%$ of the total variance. Bunchgrass cover, rock cover, distance to the nearest human settlement and cattle grazing were the variables with the most significant effects (Table 2). The probability of patch occupancy increased with higher per cent cover of bunchgrasses and rocks (Fig. 2a,b), but decreased in the presence of cattle grazing and in closer proximity to human settlements (Fig. 2c,d). However, the effect of the distance to human settlements was 


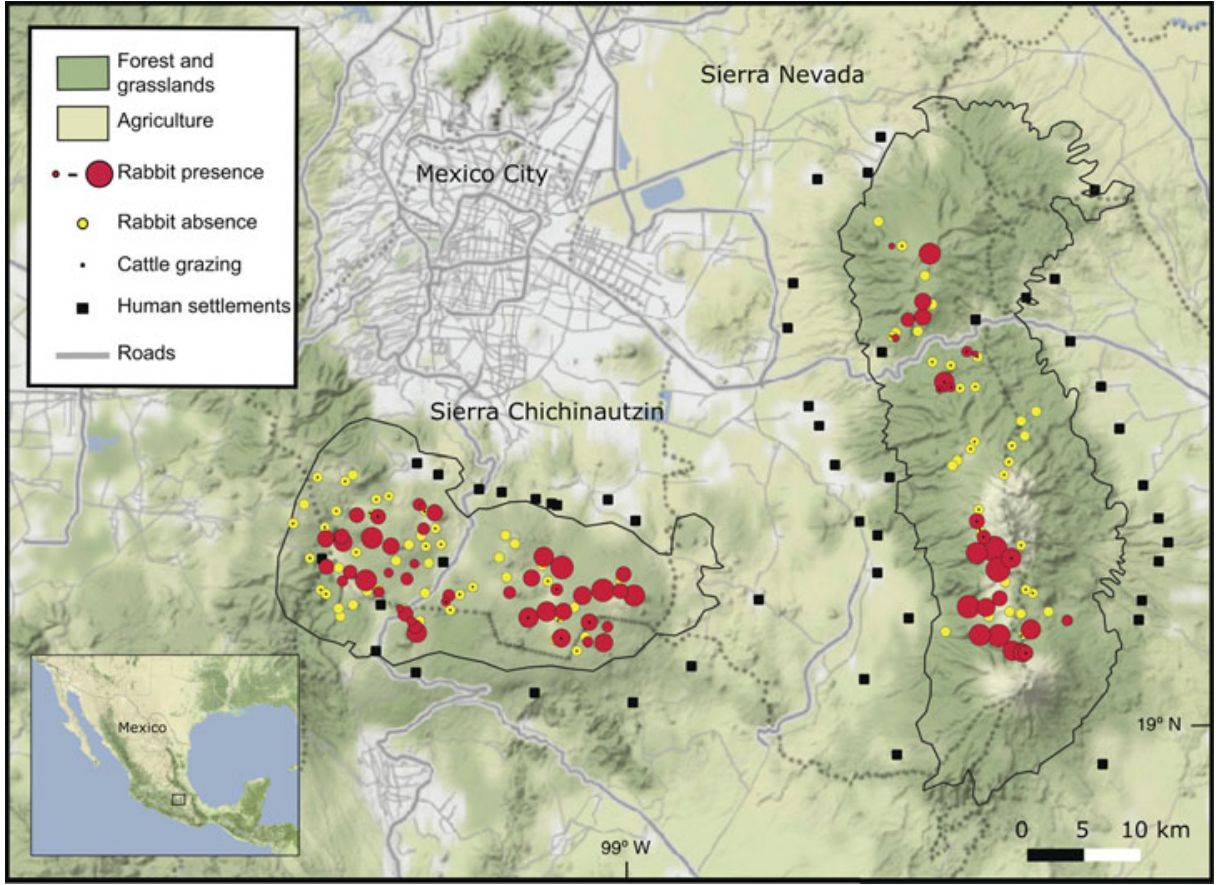

FIG. 1 Current distributional range of the volcano rabbit Romerolagus diazi in the Sierra Chichinautzin and the Sierra Nevada in central Mexico. different between the two volcanic fields (Supplementary Fig. 1a). In the Sierra Chichinautzin, the probability of patch occupancy was $<5 \%$ when human settlements were $<_{4} \mathrm{~km}$ away $(\mathrm{P}<0.05)$, but increased rapidly as distance increased $(\mathrm{P}<0.001)$. In the Sierra Nevada, we observed no significant effect for this factor $(\mathrm{P}=0.342)$.

In the Sierra Chichinautzin, the presence of cattle grazing reduced the probability of patch occupancy to $3 \%$, whereas without cattle grazing it was up to $70 \%$. However, cattle grazing did not change the probability of patch occupancy in the Sierra Nevada, where it remained at c. $50 \%$ (Supplementary Fig. 1f). Nevertheless, the variance of the probability for patch occupancy increased where cattle grazing occurred. The interaction between cattle grazing and distance to human settlements had a negative effect on patch occupancy. Volcano rabbits were nearly absent from cattle-grazed patches located less than $6 \mathrm{~km}$ from human settlements, but the probability of patch occupancy increased rapidly with increasing distance from human settlements (Supplementary Fig. 1b). In the absence of cattle grazing, the distance to human settlements did not affect the probability of patch occupancy. The interaction between presence of the Mexican cottontail and per cent shrub cover was significant. When another lagomorph was present, the probability of recording the volcano rabbit increased as shrub cover increased (Supplementary Fig. 1c). An increase in rock cover and forest cover (Supplementary Fig. 1e,f) correlated positively with patch occupancy at elevations $<3,600 \mathrm{~m}$, where these elements are common.

The model that best explained relative abundance retained eight variables and seven interactions, explaining $66 \%$ of the total variance (Table 2). The relative abundance of volcano rabbits was significantly higher in patches with $>75 \%$ of bunchgrass cover (Fig. 3a), and in those located at altitudes $>3,600 \mathrm{~m}$ (Fig. 3b). Relative abundance had a negative relationship with rock cover (Fig. 3c) and cattle grazing (Fig. 3d). Regarding interactions between variables, we detected that volcano rabbits were most abundant in patches with $>75 \%$ bunchgrass cover, $<15 \%$ shrub cover and $>25 \%$ forest cover (Supplementary Fig. 2a,b). We found an increased relative abundance of volcano rabbits as forest cover increased, if rock cover was $>15 \%$ (Supplementary Fig. 2c). The effect of bunchgrass cover was greater in the Sierra Nevada than in the Sierra Chichinautzin (Supplementary Fig. 2f). Above 3,600 m, shrub cover had a positive (Supplementary Fig. $2 \mathrm{~d}$ ) and rock cover a negative effect on relative abundance (Supplementary Fig. 2e). In the Sierra Chichinautzin the presence of the Mexican cottontail negatively affected the relative abundance of the volcano rabbit, whereas in the Sierra Nevada the effect of such sympatry was positive (Supplementary Fig. 2g).

\section{Discussion}

The probability of recording volcano rabbits and their relative abundance in occupied areas was associated with dense cover of native bunchgrasses and rocky areas at high elevations on the volcanoes surrounding Mexico City. The proximity of these mountains to one of the most populated areas in the world leads to severe habitat modifications (e.g. natural resource extraction, introduction of livestock, accidental and provoked fires) that negatively affect the volcano rabbit and many other wildlife species. 
TABLE 2 Summary of effects in the generalized linear model fitted to presence (probabilistic distribution binomial, logit link function) and relative abundance (probabilistic distribution gamma, inverse link function) of the volcano rabbit. Variables marked with * are significant for both parameters.

\begin{tabular}{|c|c|c|c|c|}
\hline \multirow[b]{2}{*}{ Variable } & \multicolumn{2}{|c|}{ Presence } & \multicolumn{2}{|c|}{ Abundance } \\
\hline & $\chi^{2}$ & $\mathrm{P}$ & $\chi^{2}$ & $\mathrm{P}$ \\
\hline Altitude & 0.024 & 0.8760 & 7.119 & 0.0081 \\
\hline Bunchgrass cover* & 5.357 & 0.0206 & 5.213 & 0.0224 \\
\hline Cattle grazing $^{\star}$ & 16.378 & $<0.0001$ & 7.852 & 0.0056 \\
\hline Forest cover & 0.820 & 0.3652 & 0.011 & 0.9127 \\
\hline Distance to nearest settlement & 5.239 & 0.0221 & & \\
\hline Shrubs cover & 2.996 & 0.0835 & 3.711 & 0.0524 \\
\hline Sierra & 0.026 & 0.8714 & 1.954 & 0.1560 \\
\hline Sylvilagus cunicularius & 1.003 & 0.3166 & 0.629 & 0.4178 \\
\hline Rock cover ${ }^{*}$ & 11.549 & 0.0007 & 4.742 & 0.0291 \\
\hline Altitude $\times$ Cattle grazing & 0.638 & 0.4246 & & \\
\hline Altitude $\times$ Forest cover & 11.687 & 0.0006 & & \\
\hline Altitude $\times$ Rock cover ${ }^{*}$ & 18.012 & $<0.0001$ & 9.515 & 0.0025 \\
\hline Altitude $\times$ Shrubs cover & & & 37.376 & $<0.0001$ \\
\hline Altitude $\times$ Sierra & 1.710 & 0.1909 & & \\
\hline Altitude $\times$ Sylvilagus cunicularius & 1.288 & 0.2565 & & \\
\hline Bunch grass cover $\times$ Forest cover & & & 8.523 & 0.0040 \\
\hline Bunch grass cover $\times$ Rock cover & 1.964 & 0.1611 & & \\
\hline Bunch grass cover $\times$ Shrubs cover & & & 9.179 & 0.0029 \\
\hline Bunch grass cover $\times$ Sierra & & & 10.291 & 0.0017 \\
\hline Cattle grazing $\times$ Distance to settlements & 11.599 & 0.0007 & & \\
\hline Cattle grazing $\times$ Sierra & 13.836 & 0.0002 & & \\
\hline Cattle grazing $\times$ Sylvilagus cunicularius & 1.340 & 0.2471 & & \\
\hline Forest cover $\times$ Rock cover & & & 9.296 & 0.0027 \\
\hline Distance to settlements $\times$ Sierra & 8.118 & 0.0044 & & \\
\hline Rock cover $\times$ Shrubs cover & 1.932 & 0.1645 & & \\
\hline Shrubs cover $\times$ Sylvilagus cunicularius & 9.905 & 0.0016 & & \\
\hline Sierra $\times$ Sylvilagus cunicularius & & & 15.574 & 0.0002 \\
\hline
\end{tabular}

\section{Biotic factors}

Bunchgrasses are a primary resource that defines habitat suitability for the volcano rabbit throughout its range; this is consistent with previous local reports (Velázquez et al., 1996; Hunter \& Creswell, 2015) and can be explained by the species' ecology. Bunchgrasses represent $>50 \%$ of the volcano rabbit's diet (Cervantes et al., 1992; MartínezGarcía et al., 2012). As the rabbits move through the habitat, the grasses are bent, forming tunnels and passages that provide cover from predators (Cervantes, 1981). These runways are marked with latrines to define territories. The rabbits also use bunchgrasses as nest-building material, and the base of well-developed bunches as nests (Velázquez et al., 1996). The model constructed for relative abundance detected that the interactions of bunchgrass cover with shrub cover, forest cover and identity of the volcanic field were significant, but in all cases the relative abundance was greater in those patches that had bunchgrass cover $>75 \%$. This degree of habitat specificity is comparable to that of the pygmy rabbit Brachylagus idahoensis. This species is distributed in the western USA and is associated with plants of the genus Artemisia (Schmalz et al., 2014).
Volcano and pygmy rabbits are the two smallest leporid species, both with a mean weight $<500 \mathrm{~g}$ (Green \& Flinder, 1980; Cervantes et al., 1990).

Sympatry between volcano rabbits and other Mexican rabbits seems to be mediated by shrub cover. The presence of shrubs may indicate better habitat quality, and therefore allow the co-occurrence of species sharing similar niches. Another possibility is that competition for bunchgrasses may force volcano rabbits into areas with denser shrub cover. To assess the likelihood of these scenarios, it would be necessary to carry out studies that include experimental manipulation (e.g. shrub removal, shrub cover modification). At elevations $>3,600 \mathrm{~m}$ the relative abundance of the volcano rabbit was higher in patches with denser shrub cover. It has been reported that during times of harsh environmental conditions (cold and dry winter months when grasses are scarce), volcano rabbits increase their consumption of shrubs (shrubs comprise $1.3 \%$ of their diet in the rainy season and up to $12.8 \%$ in the dry season; Cervantes \& Martínez, 1992). This increased consumption of shrubs could also occur in the more restrictive environmental conditions near the upper elevation limit of the species' distribution. 

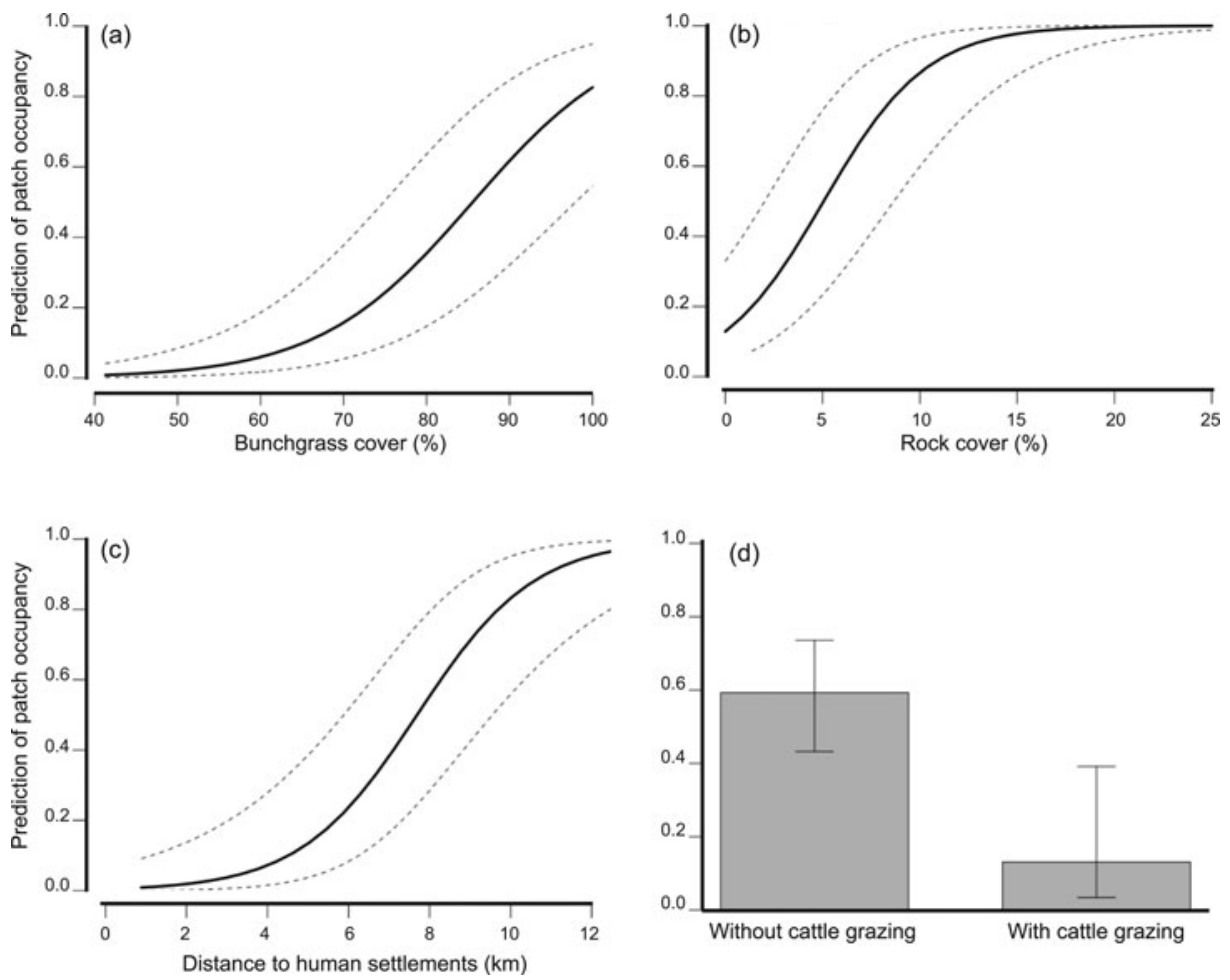

FIG. 2 Influence of the main variables on patch occupancy by volcano rabbits. The proportion of bunchgrass (a) and rock cover (b) were the essential factors that made a patch suitable for the volcano rabbit. Proximity to human settlements (c) and livestock grazing decreased volcano rabbit occupancy (d).
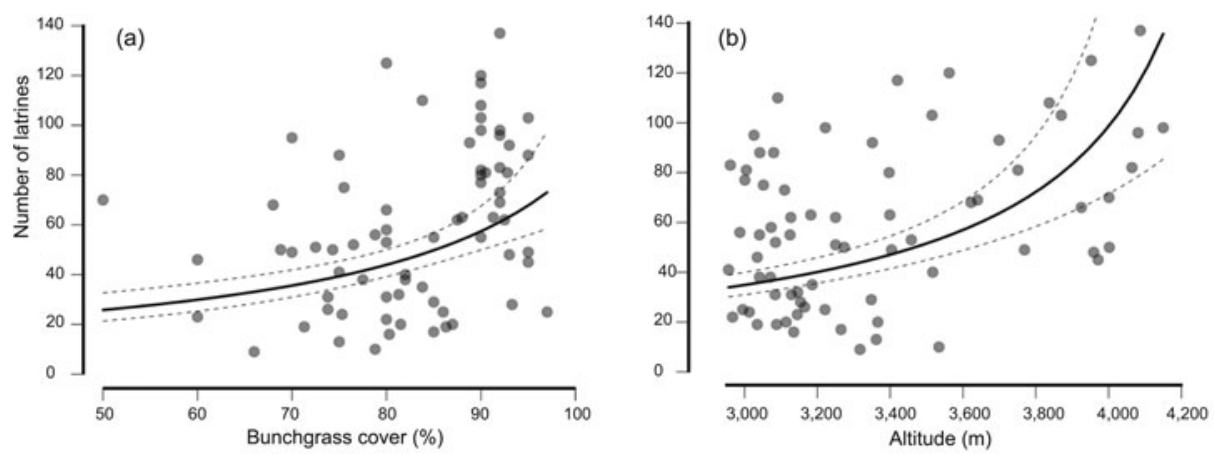

Fig. 3 Influence of the variables on relative abundance of the volcano rabbit. The proportion of bunchgrass cover shows a positive relationship with the relative abundance (a). Bunchgrass is a vital resource that is used as food, protection against predators, and as nesting material. As altitude increases, tree cover and abundance of other plants
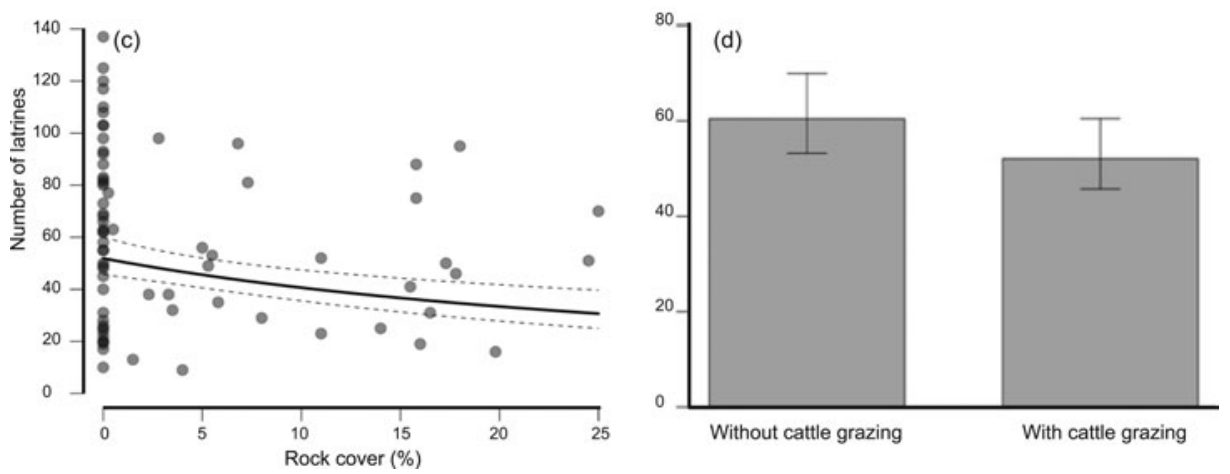
decrease, leaving patches composed mainly of bunchgrasses and increasing the relative abundance of rabbits (b). Although rocks are another basic resource, a high per cent of rock cover reduces the area available for bunchgrasses and thus reduces the relative abundance of volcano rabbits (c). Relative abundance is affected negatively by the presence of livestock (d).

Sympatry with the Mexican cottontail was negatively correlated with the relative abundance of the volcano rabbit in the Sierra Chichnautzin, but positively correlated in the Sierra Nevada. Higher levels of human disturbance (human impact index of 0.7 in the Sierra Chichinautzin vs 0.6 in the Sierra Nevada; Table 1) may indicate lower habitat quality in the Sierra Chichinautzin, which could intensify competition between the volcano rabbit and other lagomorphs (Leach et al., 2015). This finding is consistent with high levels of physiological stress (inferred by the amount of cortisol and its derivatives measured in the excreta) reported for the volcano rabbit in some patches in the Sierra Chichinautzin 
(Rizo-Aguilar et al., 2014). In the larger areas of grassland away from human influence in the Sierra Nevada the rabbits may experience less pressure on resources such as food and shelter. It is also possible that sympatry with other lagomorphs could be positive for the volcano rabbit in these areas because of reduced predation pressure. However, studies with an experimental design would be required to examine these interspecific interactions more thoroughly.

\section{Abiotic factors}

Rock cover was determinant for the presence and relative abundance of the volcano rabbit. The probability of patch occupancy was highest where rock cover was $5-15 \%$ but the relative abundance of rabbits in those patches was lower than in occupied patches with rock cover $<5 \%$. For small mammals such as the volcano rabbit, rocks may act as refuges that facilitate predator avoidance (Alves et al., 2008). The species exhibits social aggregation and is the only leporid that vocalizes (Velázquez et al., 1996). Sometimes it is possible to observe individuals on rocks, keeping watch and emitting alerts to the group if a threat is detected. However, sites with a rock cover $>15 \%$ are characterized by a low relative abundance of volcano rabbits, as a greater per cent of rock cover means less bunchgrass cover.

The effect of elevation on relative abundance reflects the species' habitat preference, considering that bunchgrasses predominate at elevations $>3,600 \mathrm{~m}$ (Velázquez \& Heil, 1996; Velázquez et al., 1996). Typically, at elevations $<3$,000 m habitat patches are small and with substantial tree cover (Abies spp., Alnus spp. and Pinus spp.), isolated by a forest matrix mixed with agricultural fields. Large habitat patches (with high relative abundance of volcano rabbits) can also be found at altitudes of $3,000-3,600 \mathrm{~m}$ in grasslands with pine forest, characterized by the predominance of M. macroura-Pinus spp. or F. tolucensis-Pinus spp. At elevations $>3,600 \mathrm{~m}$, there are extensive areas of subalpine and alpine grasslands (e.g. Festuca spp., Muhlenbergia spp. and Calamagrostis spp.), with large habitat patches in a matrix that is permeable to movements of volcano rabbits. Our findings differ from those of Velázquez \& Heil (1996), who reported a negative correlation between elevation and the relative abundance of volcano rabbits in the Sierra Chichinautzin. This discrepancy could be attributable to sampling design: the highest elevations of the Sierra Chichinautzin are $<3,700 \mathrm{~m}$, so there may have been few suitable patches for the volcano rabbit at the study site of Velázquez \& Heil (1996).

The interactions between rock cover and elevation, and between rock cover and forest cover, appeared to be a result of spatial autocorrelation between these factors. At elevations $<3,600 \mathrm{~m}$, as in the Sierra Chichinautzin, $36 \%$ of the patches of suitable habitat have rocks, and the mean rock cover in occupied patches was $5.8 \%$. At elevations $>3,600 \mathrm{~m}$, as in most of the Sierra Nevada, $10 \%$ of the patches of suitable habitat have rocks and the occupied patches averaged $1.7 \%$ of rock cover. The existence of larger and more connected patches in the Sierra Nevada compared to the Sierra Chichinautzin leads to a greater probability of detecting the presence of volcano rabbits even when the rock cover in some of those patches is $<5 \%$. The positive effect of forest cover on volcano rabbit presence at elevations $<3,600 \mathrm{~m}$ can be explained by the fact that forest can be extensive at those elevations, whereas at higher elevations forest cover is naturally lower. In both sierras, large proportions of forest cover may indicate low levels of human disturbance, and thus an increased probability of species detection. In addition, it has been reported that volcano rabbits feed on leaves of Alnus spp. (Cervantes \& Martínez, 1992), which is common in both sierras at elevations $<3,600 \mathrm{~m}$ and contributes significantly to forest cover.

\section{Anthropogenic factors}

We found that cattle grazing and close proximity to human settlements significantly reduced occupancy by volcano rabbits, particularly in the Sierra Chichinautzin. This suggests that this species, like other habitat specialists, is sensitive to human disturbance. Human impact on ecosystems leads to the loss of specific resources, in this case bunchgrasses. A negative effect of anthropogenic disturbances on habitat specialists has been demonstrated in other studies (Pierce et al., 2011; Dendup et al., 2017; Zhao et al., 2017). We found that the presence of livestock grazing primarily affected patch occupancy, but had little effect on relative abundance. It is possible that this could be the effect of recent cattle introduction to patches that have long been used by rabbits.

Cattle feed mainly on bunchgrasses, and the way in which they graze reduces grass cover and alters its natural structure. High rates of fires are also associated with grazing because of prescribed burning during the dry season to stimulate pasture regrowth (Blanco et al., 1981). Fires are a major threat to lagomorph conservation (Portales et al., 1997). Burning pasture is a common activity throughout the entire range of the volcano rabbit, causing numerous uncontrolled fires that devastate hundreds of hectares of grasslands per year. Other factors that reduce habitat quality in the vicinity of human settlements (Velázquez et al., 1996) include agriculture, wood extraction, removal of fertile soil, hunting, road construction, pollution and presence of feral fauna. These factors need to be taken into account when planning and implementing conservation actions.

\section{Implications for conservation}

Our findings can contribute to the design and development of effective conservation plans for the volcano rabbit and its habitat. The species' dependence on bunchgrasses makes 
the protection of the natural grasslands in the Sierra Chichinautzin and the Sierra Nevada a matter of high importance. We found that the presence of livestock and probably other factors such as fires and agricultural expansion may represent a threat to this key resource, with grazing directly affecting bunchgrass cover and structure. Mitigating the impact of cattle grazing is a priority at both volcanic fields because of its negative effect that can lead to local extirpation of volcano rabbit populations. Furthermore, the lack of trained personel to enforce the current regulations (SEMARNAT, 2012; DOF, 2018) limiting the exploitation of natural resources is a serious problem. In addition to increasing capacity for law enforcement, environmental education programmes should be established. These measures could support the conservation of not only the volcano rabbit, but also other wildlife species in these ecosystems.

An imminent threat that has not been evaluated is afforestation of grassland areas at both sierras. The impact of such artificial creation of forest on the habitat of the volcano rabbit should be evaluated. In addition, a long-term monitoring programme for the volcano rabbit should be established, to examine the effects of both the natural components of the habitat and human disturbances on the dynamics of extinction and recolonization of local populations of the volcano rabbit and other endemic species.

Acknowledgements We thank C. Osuna, F. Osuna and M. Uriostegui for their support during fieldwork; The Rufford Foundation for financial support (Rufford Small Grant 21227-1); and A. Smith and one anonymous reviewer for their critiques. FO received a Graduate Student Scholarship from CONACyT México (ID: 295207). This manuscript is submitted in partial fulfilment of the requirements for the degree Doctorado en Ciencias of the graduate student programme at the Instituto de Ecologia AC, México.

Author contributions Project design: all authors; logistic support: AEM; fieldwork: FO; data analyses: FO, RG; writing: FO, RG, AEM.

\section{Conflicts of interest None.}

Ethical standards This research abided by the Oryx guidelines on ethical standards. No animals were collected or handled, and site surveys had minimal impact on the habitat.

\section{References}

Alves, P.C., Ferrand, N. \& Hackländer, K. (2008) Lagomorph Biology: Evolution, Ecology and Conservation. Springer Verlag, Berlin Heidelberg, Germany.

Arregoitia, L.V., Leach, K., Reid, N. \& Fisher, D.O. (2015) Diversity, extinction, and threat status in lagomorphs. Ecography, $38,1115-1165$.

Blanco, S., Ceballos, G., Galindo, C., Maas, M., Patrón, R., Pescador, A. \& SuÁrez, A. (1981) Ecología de la Estación Experimental Zoquiapan. Cuadernos Universitarios, Universidad Autónoma de Chapingo, Chapingo, Mexico.

Cervantes, F.A. (1981) Some predators of the zacatuche (Romerolagus diazi). Journal of Mammalogy, 62, 850-851.
Cervantes, F.A. \& Martínez, J. (1992) Food habits of the rabbit Romerolagus diazi (Leporidae) in central Mexico. Journal of Mammalogy, 73, 830-834.

Cervantes, F.A., Lorenzo, C. \& Hoffmann, R.S. (1990) Romerolagus diazi. Mammalian Species, 360, 1-7.

Cervantes, F.A., Lorenzo, C., Vargas, J. \& Holmes, T. (1992) Sylvilagus cunicularius. Mammalian Species, 412, 1-4.

CONABIO (2018) Modelo Espacial de Impactos a la Biodiversidad Mexicana, MEXBIO. Resolución $1 \mathrm{~km}^{2}$. Comisión Nacional para el Conocimiento y Uso de la Biodiversidad, Mexico City, Mexico.

Crown, C. \& van Riper, C. (2010) Avian community responses to mechanical thinning of a pinyon-juniper woodland: specialist sensitivity to tree reduction. Natural Areas Journal, 30, 191-201.

Dendup, P., Cheng, E., Lham, C. \& Tenzi, U. (2017) Response of the Endangered red panda Ailurus fulgens fulgens to anthropogenic disturbances, and its distribution in Phrumsengla National Park, Bhutan. Oryx, 51, 701-708.

dof (Diario Oficial de la Federación) (2018) Ley General de Vida Silvestre. Diario Oficial de la Federación. 19 January 2018, Mexico City, Mexico.

Domínguez, P.A. (2007) Efecto del cambio climático en la distribución del conejo endémico de México Romerolagus diazi. Bachelor's thesis, Universidad Nacional Autónoma de México, Mexico City, Mexico.

Edgel, R.J., Pierce, J.L. \& Larson, R.T. (2014) Pygmy rabbit (Brachylagus idahoensis) habitat selection: does sagebrush (Artemisia spp.) age influence selection? Western North American Naturalist, 74, 145-154.

Fa, J.E., Romero, F.J. \& Lopez-Paniagua, J. (1992) Habitat use by parapatric rabbit in a Mexican high-altitude grassland system. Journal of Applied Ecology, 29, 357-370.

Galicia, L. \& García-Romero, A. (2007) Land use and land cover change in highland temperate forest in the Izta-Popo National Park, central Mexico. Mountain Research and Development, 27, 48-57.

Green, J.S. \& Flinder, J.T. (1980) Brachylagus idahoensis. Mammalian Species, 125, 1-4.

Hunter, M. \& Creswell, W. (2015) Factors affecting the distribution and abundance of the Endangered volcano rabbit Romerolagus diazi on the Iztaccihuatl volcano, Mexico. Oryx, 49, 366-375.

ineGi (Instituto Nacional de Estadística y Geografía, México) (2013) Continuo de Elevaciones Mexicano 3.o (CEM 3.o). inegi.org.mx/app/geo2/elevacionesmex [accessed 13 June 2019].

KolasA, J. \& Li, B.L. (2003) Removing the confounding effect of habitat specialization reveals the stabilizing contribution of biodiversity to species variability. Proceedings of the Royal Society B, 270, 198-201.

Krebs, C.J., Gilbert, B.S., Boutin, S. \& Boonstra, R. (1986) Estimation of snowshoe hare populations density from turd transects. Canadian Journal of Zoology, 65, 565-567.

Leach, K., Montgomery, W.I. \& Reid, N. (2015) Biogeography, macroecology and species' traits mediate competitive interactions in the order Lagomorpha. Mammal Review, 45, 88-102.

Márquez, A., Verma, S.P., Anguita, F., Oyarzun, R. \& Brandle, J.L. (1999) Tectonics and volcanism of Sierra Chichinautzin: extension at the front of the Central Trans-Mexican Volcanic Belt. Journal of Volcanology and Geothermal Research, 93, 125-150.

Martínez-García, J.A., Mendoza, G.D., Alcantara, J.L., Tarango, L.A., Sánchez, T., Rodríguez, R. \& Hernández, P.A. (2012) Composición de la dieta y capacidad nutricional de carga del hábitat del conejo de los volcanes (Romerolagus diazi) en México. Revista Chapingo, Serie Ciencias Forestales y del Ambiente, $18,423-434$.

Monroy, M.R., Pino, M.J.M., Lozano, G.M.A. \& García, F.A. (2011) Estudio etnomastozoológico en el Corredor Biológico Chichinautzin. Sitientibus Série Ciéncias Biológicas, 11, 16-23. 
Mueller-Dombois, D. \& Ellenberg, H. (1974) Aims and Methods of Vegetation Ecology. John Wiley, New York, USA.

Osuna, F., Gonzalez, D., Espinosa de los Monteros, A. \& Guerreo, J.A. (2020) Phylogeography of the volcano rabbit (Romerolagus diazi): the evolutionary history of a mountain specialist moulded by the climatic-volcanism interaction in the central Mexican highlands. Journal of Mammalian Evolution, 27, 745-757.

Pierce, J.E., Larsen, R.T., Flinders, J.T. \& Whiting, J.C. (2011) Fragmentation of sagebrush communities: does an increase in habitat edge impact pygmy rabbits? Animal Conservation, 14, 314-321.

Portales, G.L., Reyes, P., Rangel, H., Velazquez, A., Miller, P., ElLis, S. \& Sмiтн, A.T. (1997) Taller Internacional para la Conservacion de los Lagomorfos Mexicanos en Peligro de Extinción. IUCN/SSC Conservation Breeding Specialist Group, Apple Valley, USA

QGIS Development Team (2009) QGIS Geographic Information System 3.1. Open Source Geospatial Foundation Project. qgis.org [accessed 13 June 2019].

R Development Core Team (2012) R: A Language and Environment for Statistical Computing. R Foundation for Statistical Computing, Vienna, Austria.

Rizo-Aguilar, A., Guerrero, J.A., Montoya-Lara, A.M.P. \& Valdespino, C. (2014) Physiological stress in volcano rabbit Romerolagus diazi populations inhabiting contrasting zones at the Corredor Biológico Chichinautzin, Mexico. Mammalian Biology, 79, 357-361.

Rizo-Aguilar, A., Guerrero, J.A., Hidalgo-Mihart, M.G. \& GonzÁlez-Romero, A. (2015) Relationship between the abundance of the Endangered volcano rabbit Romerolagus diazi and vegetation structure in the Sierra Chichinautzin mountain range, Mexico. Oryx, 49, 360-365.

Rizo-Aguilar, A., Delfin-Alonso, C., Gonzalez-Romero, A. \& Guerrero, J.A. (2016) Distribution and density of the zacatuche rabbit (Romerolagus diazi) at the protected natural area 'Corredor Biologico Chichinautzin'. Therya, 7, 333-342.

Rzedowski, J. (1988) Vegetación de México. Limusa, Mexico City, Mexico.

Santilli, F., Bagliacca, M. \& Paci, G. (2015) Density and habitat use of sympatric brown hares and European rabbits in a Mediterranean farmland area of Tuscany (central Italy). Ethology Ecology \& Evolution, 27, 233-243.
Schmalz, J.M., Wachocki, B., Wright, M., Zeveloff, S.I. \& Skорес, M.M. (2014) Habitat selection by the pygmy rabbit (Brachylagus idahoensis) in Northeastern Utah. Western North American Naturalist, 74, 456-466.

Semarnat (Secretaria de Medio Ambiente y Recursos Naturales) (2010) Norma Oficial Mexicana

NOM-059-SEMARNAT-2010. Protección Ambiental-Especies Nativas de México de Flora y Fauna Silvestres-Categorías de Riesgo y Especificaciones para su Inclusión, Exclusión o Cambio-Lista de Especies en Riesgo. Diario Oficial de la Federación 2a sección, Mexico City, Mexico.

Semarnat (Secretaria de Medio Ambiente y Recursos Naturales) (2012) Reglamento Interior de la Secretaría de Medio Ambiente y Recursos Naturales. Diario Oficial de la Federación, 26 November 2012. Mexico City, Mexico.

Trejo, I. \& Dirzo, R. (200o) Deforestation of seasonally dry tropical forest: a national and local analysis in Mexico. Biological Conservation, 94, 133-142.

United States Department of State Geographer (2018) Google Earth Pro. Google Earth. google.com/intl/es/earth [accessed 13 June 2019].

Uriostegui-Velarde, J.M., Gonzalez-Romero, A., Pineda, E., Reyna-Hurtado, R., Rizo-Aguilar, A. \& Guerrero, J.A. (2018) Configuration of the volcano rabbit (Romerolagus diazi) landscape in the Ajusco-Chichinautzin mountain range. Journal of Mammalogy, 99, 263-272.

Velázquez, A. \& Heil, G.W. (1996) Habitat suitability study for the conservation of the volcano rabbit (Romerolagus diazi). Journal of Applied Ecology, 33, 543-554.

Velázquez, A. \& Guerrero, J.A. (2019) Romerolagus diazi. In The IUCN Red List of Threatened Species 2019: e.T19742A45180356. dx.doi.org/10.2305/IUCN.UK.2019-2.RLTS.T19742A45180356.en [accessed 22 October 2020].

Velázquez, A., Romero, F.J. \& López-Paniagua, J. (1996) Ecología y conservación del conejo zacatuche (Romerolagus diazi) y su hábitat. Fondo de Cultura Económica, Mexico City, Mexico.

Zhao, C., Yue, B., Ran, J., Moermond, T., Hou, N., Yang, X. \& Gu, X. (2017) Relationship between human disturbance and Endangered giant panda Ailuropoda melanoleuca habitat use in the Daxiangling Mountains. Oryx, 51, 146-152. 